\title{
Jurist-Diction
}

Volume 3 No. 5, September 2020

\section{Pekerja Rumah Tangga Sebagai Korban Kekerasan Dalam Rumah Tangga}

\author{
Erita Rosa Larasati Daud \\ eritarosa@gmail.com \\ Universitas Airlangga
}

\begin{abstract}
How to cite:
Erita Rosa Larasati Daud, 'Pekerja Rumah Tangga

Sebagai Korban Kekerasan Dalam Rumah Tangga' (2020)

Vol. 3 No. 5 Jurist-Diction.

Histori artikel:

Submit 9 Juli 2020;

Diterima 14 Agustus 2020;

Diterbitkan 1 September 2020.

DOI:

10.20473/jd.v3i5.21973
\end{abstract}

\begin{abstract}
Abstrak
Artikel yang berjudul "Pekerja Rumah Tangga Sebagai Korban Kekerasan Dalam Rumah Tangga" berlandaskan pada penelitian yuridis normatif dengan pendekatan perundang-undangan dan pendekatan konseptual. Peraturan perundang-undangan yang mengatur mengenai "Pekerja Rumah Tangga Sebagai Korban Kekerasan Dalam Rumah Tangga" ada di dalam Undang-Undang Nomor 23 Tahun 2004 mengenai Penghapusan Kekerasan Dalam Rumah Tangga dan Peraturan Menteri Ketenagakerjaan Nomor 2 Tahun 2015 Tentang Perlindungan Pekerja Rumah Tangga. Penelitian ini bertujuan untuk mengetahui dan menganalisis perlindungan hukum bagi Pekerja Rumah Tangga yang menjadi korban KDRT. Salah satu penyelesaian kasus tindak pidana KDRT yaitu terdapat upaya non litigasi berupa mediasi penal dimana kedua pihak dipertemukan dengan ditengahi oleh Pihak Kepolisian untuk menyelesaikan kasus KDRT. Untuk upaya ini belum diatur dalam Undang-Undang Nomor 23 Tahun 2004, sehingga mediasi penal tidak memiliki dasar peraturan perundang-undangan yang mengatur dengan jelas prosedur dan tata caranya serta hanya berdasar dari kewenangan diskresi dari Undang-Undang Kepolisian. Sehingga untuk upaya mediasi penal yang belum diatur secara tegas dalam UU PKDRT, Penulis memberi saran untuk revisi UU PKDRT, pembuat undang-undang memasukkan mediasi penal sebagai salah satu alternatif penyelesaian masalah KDRT agar terdapat dasar hukum yang jelas.

Kata Kunci: Pekerja Rumah Tangga; Korban Kekerasan Dalam Rumah Tangga; Perlindungan Hukum.
\end{abstract}

\section{Pendahuluan}

Dalam era modern saat ini manusia berlomba-lomba untuk mencari pekerjaan demi memenuhi kebutuhan hidupnya. Mereka akan melakukan apapun untuk mendapatkan pekerjaan termasuk dengan mengandalkan kemampuan yang mereka miliki. Indonesia merupakan negara dengan salah satu pekerjaan terbanyak yaitu Pekerja Rumah Tangga (untuk selanjutnya disebut PRT). Pekerjaan tersebut banyak diminati karena dinilai tidak membutuhkan syarat yang rumit dan cukup mengandalkan kemampuan sehari-hari seperti memasak, membersihkan rumah, 
mencuci baju, dan lain-lain. Namun hingga saat ini ada sebagian orang yang tidak mengetahui jika sesungguhnya PRT itu masuk dalam lingkup rumah tangga karena menilai lingkup rumah tangga hanya Ayah, Ibu, dan Anak saja.

Rumah tangga memiliki pengertian yaitu merupakan kumpulan dari masyarakat terkecil yang terdiri dari suami, istri, anak-anak, mertua, dan orang lain yang menempati rumah tersebut. Terwujudnya rumah tanggga yang sah terjadi setelah akad nikah atau perkawinan, sesuai dengan ajaran agama dan yang terdapat dalam Undang- Undang khususnya Undang-Undang 16 Tahun 2019 tentang Perubahan Atas Undang-Undang Nomor 1 Tahun 1974 tentang Perkawinan. ${ }^{1}$

Lingkup rumah tangga menurut Pasal 2 Undang-Undang Nomor 23 Tahun 2004 tentang Penghapusan Kekerasan Dalam Rumah Tangga (untuk selanjutnya disebut UU PKDRT) meliputi :

a. Suami, isteri, dan anak;

b. Orang-orang yang mempunyai hubungan keluarga dengan orang sebagaimana dimaksud pada huruf a karena hubungan darah, perkawinan, persusuan, pengasuhan dan perwalian, yang menetap dalam rumah tangga; dan atau

c. Orang yang bekerja membantu rumah tangga dan menetap dalam rumah tangga tersebut.

Dalam lingkup rumah tangga yang berada di Pasal 2 UU PKDRT, PRT termasuk dalam lingkup rumah tangga dan merupakan bagian dari keluarga, yang berarti jika PRT mengalami kekerasan oleh anggota rumah tangga yang Ia tinggali atau Ia tempati kekerasan tersebut akan masuk dalam kategori Kekerasan Dalam Rumah Tangga (untuk selanjutnya disebut KDRT).

PRT sendiri menurut Konvensi Perburuhan Internasional Nomor 189 tentang Pekerjaan yang Layak Bagi PRT memiliki pengertian yaitu setiap orang yang terikat di dalam pekerjaan rumah tangga dalam suatu hubungan kerja. Seseorang yang melaksanakan pekerjaan rumah tangga hanya secara kadang- kadang dan bukan sebagai sarana untuk mencari nafkah, bukan merupakan PRT.

1 Sidi Nazar Bakry, Kunci Keutuhan Rumah Tangga (Akademik Pressindo 1993).[26]. 
Indonesia hingga saat ini belum memiliki Undang-Undang yang mengatur Perlindungan PRT, penyebabnya Rancangan Undang-Undang PRT belum juga dibahas di DPR walaupun sudah diajukan di ke Parlemen semenjak 13 tahun lalu. Oleh karena belum ada peraturan yang mengikat tersebut maka PRT belum diakui sebagai pekerja dan tidak ada yang memandatkan bahwa PRT berhak atas jaminan kesehatan dan jaminan ketenagakerjaan serta tidak memiliki wadah hukum dan tidak dijamin perlidungannya oleh hukum.

Jika dilihat dari kacamata awam sejatinya PRT memiliki risiko yang besar mendapat kekerasan baik secara fisik maupun psikis karena terkait tugasnya untuk diperintah-perintah oleh Majikan yang merasa memiliki posisi lebih tinggi dari PRT. Menurut survey Organisasi Buruh Internasional Tahun 2016 di Indonesia sendiri terdata PRT berjumlah sebanyak 2.593.399 yang mayoritas berjenis kelamin perempuan dengan kenyataan di lapangan PRT sering mendapat perlakuan yang tidak adil masalah upah dan sering mendapat kekerasan fisik maupun pelecehan seksual. ${ }^{2}$

Data tersebut menunjukkan bahwa untuk saat ini perlindungan hukum merupakan hal yang sangat dibutuhkan oleh PRT, serta perlindungan hukum juga merupakan hal yang penting karena kerkaitannya dengan Hak Asasi Manusia dan dengan jumlah PRT yang sangat banyak di Indonesia maka PRT pantas mendapatkan perlindungan yang tegas atas pekerjaannya tersebut.

Beranjak dari pentingnya perlindungan hukum bagi PRT, maka penelitian ini akan berfokus pada perlindungan hukum PRT yang menjadi korban KDRT ditinjau dari Undang-Undang Nomor 23 Tahun 2004 Tentang Penghapusan Kekerasan Dalam Rumah Tangga dan juga dengan melihat peraturan lain yang relevan.

\section{Konsep Perlindungan Hukum}

Perlindungan secara umum dalam Kamus Besar Bahasa Indonesia (untuk selanjutnya disebut KBBI) memiliki 2 (dua) pokok pengertian yaitu merupakan tempat berlindung dan atau perbuatan yang melindungi. Hal tersebut dimaksudkan

2 Edriana Noerdin, Potret Kemiskinan Perempuan (Women Research Institute 2006).[139-140]. 
perlindungan adalah tindakan untuk melindungi sesuatu atau seseorang dari pihak tertentu dengan menggunakan cara-cara tertentu. Sedangkan dalam Black's Law Dictionary, protection diartikan sebagai the act of protecting.

Menurut Philipus M. Hadjon perlindungan hukum merupakan perlindungan akan harkat dan martabat, serta pengakuan terhadap hak-hak asasi manusia yang dimiliki subyek hukum berdasarkan ketentuan hukum dari kesewenangan serta perlindungan hukum sebagai kumpulan peraturan atau kaidah yang akan dapat melindungi suatu hal dari hal lainnya. ${ }^{3}$

Pasal 1 ayat (4) UU PKDRT memberikan definisi perlindungan hukum sebagai segala upaya yang bertujuan untuk memberikan rasa aman kepada korban yang dilakukan oleh pihak keluarga, Advokat, Lembaga Sosial, Kepolisian, Kejaksaan, Pengadilan, atau pihak lainnya, baik yang bersifat sementara maupun berdasarkan penetapan dari Pengadilan.

Dari 2 (dua) pendapat diatas dapat disimpulkan bahwa perlindungan hukum merupakan segala upaya yang diberikan oleh hukum yang dilakukan oleh lembaga-lembaga tertentu seperti Kepolisian, Pengadilan, dan pihak-pihak lainnya yang berkaitan dengan hak dan kewajiban korban untuk memberikan rasa aman bagi korban tersebut. Perlindungan hukum memiliki 3 (tiga) prinsip dasar yaitu berupa:

\section{Teori Utilitas}

Teori ini berpendapat bahwa perlindungan dianggap perlu dilakukan karena kemanfaatan yang terjadi karena perlindungan tersebut lebih besar dibanding dengan tidak dilakukannya perlindungan. Kemanfaatan tersebut tidak hanya untuk korban saja namun untuk sistem penegakan pidana keseluruhan.

2. Teori Tanggung Jawab

Pada hakekatnya teori ini berpendapat bahwa setiap subjek hukum yang terdiri dari orang atau kelompok wajib bertanggung jawab atas perbuatan hukum yang dilakukannya, khususnya jika perbuatan tersebut mengakibatkan kerugian bagi 
orang lain, kecuali jika ditemukan alasan yang membuatnya bebas dari kewajiban bertanggung jawabnya tersebut.

\section{Teori Ganti Kerugian}

Teori ini menegaskan bahwa sebagai wujud dari tanggung jawab karena kesalahan subjek hukum terhadap orang lain, maka pelaku tindak pidana dibebani kewajiban untuk memberikan ganti rugi bagi korban atau ahli warisnya. ${ }^{4}$

Perlindungan hukum untuk setiap orang sesungguhnya sudah dijamin secara konstitusional oleh Undang-Undang Dasar Negara Republik Indonesia (untuk selanjutnya disebut UUD NRI 1945) Pasal 28 D hingga Pasal 28 G yang meliputi mendapatkan perlindungan dan kepastian hukum secara adil dan mendapat perlakuan yang sama di depan hukum, mendapatkan hak rasa aman dan bebas dari ancaman ketakutan untuk berbuat atau tidak berbuat sesuatu, mendapatkan perlindungan untuk tidak disiksa, mendapatkan perlindungan terhadap perlakuan yang diskriminatif, dan mendapatkan perlindungan untuk saling menghormati hak asasi manusia antara satu orang dengan orang yang lain.

Bentuk perlindungan hukum secara umum yaitu sebagai berikut :

1. Preventif, merupakan upaya perlindungan yang memiliki tujuan untuk mencegah terjadinya kekerasan dan kejahatan atau pelanggaran dengan cara pengaturan kembali perundang-undangan karena terkait fungsinya untuk memberikan rambu-rambu dan batasan-batasan dalam melakukan suatu tindakan dan juga dilakukannya ketentuan hukum yang memberi perlindungan khusus; ${ }^{5}$

2. Represif, merupakan perlindungan yang diberikan setelah terjadinya tindak pidana berupa sanksi seperti penjara, denda, dan hukuman tambahan;

3. Kuratif, merupakan penanganan untuk meminimalisir adanya tindak pidana berupa penyelenggaraan pendidikan. Dalam hal ini pendidikan untuk anggota keluarga, mendorong serta memfasilitasi pengembangan masyarakat untuk peduli dan responsif terhadap kasus KDRT yang ada di sekitarnya, dan pembeian sanksi secara edukatif kepada pelaku KDRT;

4. Rehabilitatif, merupakan perlindungan untuk mengembalikan keadaan korban dalam kondisi semula sehingga dapat berfungsi lagi sebagai angota masyarakat

\footnotetext{
4 Arif Gosita, Masalah Korban Kejahatan (Akademik Pressindo 1993).[50].

5 Anggun Lestari Suryamizon, 'Perlindungan Hukum Preventif Terhadap Kekerasan Perempuan dan Anak Dalam Perspektif Hukum Hak Asasi Manusia’ (2017) 16 Jurnal Perempuan, Agama dan Jender UIN Suska.[120].
} 
yang berguna baik untuk dirinya maupun untuk anggota masyarakat lain. ${ }^{6}$

Terkait perlindungan, PRT yang menjadi korban KDRT sering dipandang sebelah mata dan dikesampingkan karena statusnya dan pekerjaannya yang dianggap rendah. Hal ini haruslah dihindari karena PRT secara hukum sama seperti pekerja lainnya yang berhak atas perlindungan hukum.

\section{Upaya Perlindungan Hukum Dalam Undang-Undang Nomor 23 Tahun 2004 Tentang Penghapusan Kekerasan Dalam Rumah Tangga}

Secara umum korban memiliki hak diantaranya yaitu mendapat atau menolak kompensasi atas penderitaan yang dapat diterima oleh dirinya sendiri maupun oleh ahli warisnya jika korban tersebut sudah meninggal dunia, mendapat pembinaan dan pemulihan atas keadaannya dan hak miliknya, menolak untuk menjadi saksi di proses peradilan bila dirasa hal tersebut membahayakan, mendapat perlindungan atas segala ancaman, mendapat penasihat hukum, dan menggunakan upaya hukum.

Adapun kewajiban korban secara umum meliputi kewajiban untuk tidak main hakim sendiri, mencegah timbulnya lebih banyak korban lagi di masyarakat, bersedia untuk dilakukannya pembinaan atas dirinya, dan menuntut kompensasi yang sesuai dengan kemampuan pelaku. ${ }^{7}$

Dalam UU PKDRT tercantum hak korban dalam Pasal 10 dan Pasal 26 yang meliputi:

a. Perlindungan dari keluarga, kepolisian, kejaksaan, advokat, pengadilan, lembaga sosial, atau pihak lain berdasarkan penetapan pengadilan;

b. Pelayanan kesehatan sesuai kebutuhan medis;

c. Penanganan khusus yang berkaitan dengan rahasia korban;

d. Pendampingan oleh pekerja sosial dan mendapat bantuan hukum sesuai tingkat proses pemeriksaan di pengadilan;

e. Pelayanan bimbingan rohani;

f. Melaporkan KDRT kepada Kepolisian yang berada di tempat korban berada maupun di tempat kejadian perkara;

6 Syahrul Ramadhan, "Perlindungan Hukum di Bidang Kesehatan Bagi Masyarakat di Desa Tamansari Kecamatan Mumbulsari Kabupaten Jember”, Skripsi Program Sarjana Universitas Jember (Universitas Jember 2015).[6].

7 Arif Gosita, Op.Cit.[53]. 
g. Memberikan kuasa kepada keluarga atau orang lain untuk melaporkan KDRT yang menimpanya.

Dengan adanya pasal-pasal yang memuat hak-hak korban ini diharapkan korban KDRT akan mendapat perlindungan dari masyarakat, dari negara maupun dari aparat yang terkait. Perlindungan tersebut dimaksudkan agar korban KDRT khususnya PRT terhindar dari ancaman kekerasan atau kekerasan yang berkepanjangan kedepannya dan menghindari dampak traumatis yang mendalam bagi PRT.

Untuk kewajiban korban dalam UU PKDRT tidak diatur lebih lanjut, namun dalam Pasal 15 mengatur kewajiban anggota masyarakat yang berbunyi "Setiap orang yang mendengar, melihat, atau mengetahui terjadinya Kekerasan Dalam Rumah Tangga wajib melakukan upaya-upaya sesuai dengan batas kemampuannya, untuk:

a. Mencegah berlangsungnya tindak pidana;

b. Memberikan perlindungan kepada korban;

c. Memberikan pertolongan darurat;

d. Membantu proses mengajukan permohonan penetapan perlindungan.

Perlindungan hukum terhadap korban diatur dalam UU PKDRT yang tercantum dalam Pasal 17 yang berbunyi "Dalam memberikan perlindungan sementara kepolisian dapat bekerjasama dengan tenaga kesehatan, pekerja sosial, relawan pendamping, dan/atau pembimbing rohani untuk mendampingi korban.”. Dari pasal tersebut tercermin bahwa ada 6 (enam) pihak yang bekerjasama untuk melindungi korban KDRT dengan fungsi masing-masing yaitu:

1. Kepolisian, yang dijelaskan lebih lanjut dalam Pasal 18 sampai Pasal 20 UU PKDRT yang berfungsi memberikan keterangan pada korban mengenai hakhaknya untuk mendapat pelayanan dan pendampingan, melakukan penyelidikan, dan kewajiban untuk melindungi korban. Dalam Kepolisian terdapat unit khusus untuk memberikan perlindungan kepada PRT yang menjadi korban KDRT yaitu unit Pelayanan Perempuan dan Anak (PPA). Kepolisian harus menggunakan ruangan khusus dalam memberikan pelayanan kepada korban KDRT;

2. Tenaga Kesehatan, yang dijelaskan dalam Pasal 21 UU PKDRT yang berfungsi untuk memeriksa dan membuat laporan tertulis terkait kesehatan korban yang berbentuk visum et repetum atas permintaan penyidik polisi yang nantinya laporan tersebut akan digunakan untuk alat bukti di dalam sidang;

3. Pekerja Sosial, yang dijelaskan dalam Pasal 22 UU PKDRT yang berfungsi 
memberikan konseling dan menguatkan korban, memberikan informasi yang dibutuhkan korban, dan mengantarkan korban ke rumah aman milik pemerintah jika korban merasa terancam;

4. Relawan Pendamping, yang dijelaskan dalam Pasal 23 UU PKDRT yang berfungsi untuk mendampingi korban di pengadilan dan membantu korban memaparkan KDRT yang dialaminya, dan memberikan penguatan secara psikologis dan fisik korban;

5. Pembimbing Rohani, yang dijelaskan dalam Pasal 24 UU PKDRT yang berfungsi untuk memberikan penjelasan kepada koran mengenai hak, kewajiban, dan memberikan penguatan iman dan taqwa kepada korban;

6. Pelayanan Advokat, yang dijelaskan dalam Pasal 25 UU PKDRT yang berfungsi untuk memberikan konsultasi hukum, mendampingi korban di tingkat penyidikan, penuntutan, dan pemeriksaan di pengadilan maupun saat mediasi serta melakukan koordinasi dengan sesama penegak hukum.

Perlindungan oleh aparat penegak hukum tersebut baru dapat dilakukan setelah adanya aduan dari PRT yang menjadi korban KDRT, karena UU PKDRT merupakan delik aduan dimana sebuah tindak pidana baru dapat diproses jika tindak pidana tersebut diadukan oleh orang yang merasa dirugikan olehnya. Oleh karena itu PRT haruslah membuat aduan terlebih dulu pada Kepolisian untuk dapat dilakukannya perlindungan dan jika tidak adanya aduan dari PRT maka Kepolisian tidak dapat memproses tindak pidana KDRT.

Perlindungan perlu dilakukan terkait dengan KDRT yang merupakan hidden crime / kejahatan yang tersembunyi karena pelaku maupun korban sama-sama merahasiakan oleh karena itulah perlu perlindungan yang tegas dan menjamin hak korban agar korban tidak takut melapor dan tidak takut untuk kejahata yang dilakukan oleh orang terdekatnya di proses di pengadilan untuk menghindari hal tersebut terjadi lagi di masa depan. ${ }^{8}$

Beberapa hambatan dalam pelaksanaan perlindungan kepada korban KDRT khususnya PRT, membuat perlindungan susah untuk diterapkan kepada korban KDRT. Hambatan tersebut banyak ditemui dalam tahap pelaporan, penyelidikan, penyidikan yang bersumber dari berbagai pihak yaitu dari pihak korban sendiri, keluarga korban, masyarakat, negara.

\footnotetext{
8 Moerti Hadiati Soeroso, Kekerasan Dalam Rumah Tangga Dalam Perspektif YuridisViktimologis (Sinar Grafika 2010).[1].
} 
Hambatan dari korban terjadi karena banyak kasus pihak korban tidak mau melapor kasusnya karena beranggapan jika hal tersebut sama saja dengan membuka aib diri sendiri, adanya pembiaran pada pelaku KDRT oleh korban karena korban merasa masih bergantung secara ekonomi pada pelaku, dan korban terlambat melaporkan kasus KDRT yang dialaminya sehingga bukti-bukti sudah hilang.

Hambatan dari pihak keluarga korban dan masyarakat berupa kurangnya dukungan keluarga pada korban untuk meneruskan kasusnya karena menganggap KDRT adalah aib keluarga yang harus ditutupi dan dilindungi serta tidak boleh diketahui oleh masyarakat lain dan harus diselesaikan dengan jalur kekeluargaan bukan melalui jalur hukum. Untuk hambatan dari negara meliputi ketentuan yang mengatur biaya visum et repertum yang memberatkan bagi beberapa orang. ${ }^{9}$

Ada beberapa alternatif untuk mengatasi hambatan-hambatan dalam perlindungan kepada korban KDRT khususnya dalam hal ini untuk PRT diantaranya:

1. Dilakukannya sosialisasi kepada masyarakat yang berbentuk penyuluhan hukum yang menyadarkan masyarakat betapa pentingnya korban KDRT untuk melaporkan kasusnya karena saat ini KDRT bukan lagi menjadi ranah privat namu sudah menjdi ranah publik;

2. Penegak hukum harus mewujudkan sistem peradilan yang berkeadilan gender, agar korban KDRT tidak merasa khawatir untuk melaporkan kasusnya ke Kepolisian;

3. Kasus KDRT yang terkadang susah untuk diproses karena kesulitan dalam pembuktian dan perkara yang dicabut oleh korban karena adanya ketergantungan ekonomi membutuhkan kerjasama dari aparat penegak hukum untuk menegakkan hak korban.

\section{Perlindungan Hukum Korban Kekerasan Dalam Rumah Tangga Menurut Kitab Undang-Undang Hukum Pidana}

Bentuk perlindungan yang dapat diberikan oleh KUHP yang memaknai kekerasan dalam Pasal 89 yang berbunyi “yang disamakan dengan melakukan 
kekerasan, membuat orang jadi pingsan atau tidak berdaya lagi (lemah)" masuk di dalam beberapa pasal diantaranya:

1. Pasal 351 KUHP

Penganiayaan biasa, penganiayaan yang mengakibat luka berat, dan penganiayaan yang mengakibatkan orang mati.

2. Pasal 352 KUHP

Penganiayaan ringan.

3. Pasal 353 KUHP

Penganiayaan berencana yang mengakibatkan luka berat dan mengakibatkan orang mati.

4. Pasal 354 KUHP

Penganiayaan berat yang di dalamnya terdapat penganiayaan berat dengan rencana dan penganiayaan berat dan rencana yang mengakibatkan orang mati.

Pasal-pasal tersebut masuk dalam kategori perbuatan penganiayaan.

Sedangkan untuk pasal lain diluar penganiayaan yang dapat dijadikan sebagai pasal yang menjerat pelaku KDRT yang korbannya dikhususkan kepada PRT diantaranya:

1. Pasal 285 KUHP

Perkosaan.

2. Pasal 286 KUHP

Bersetubuh dengan wanita di luar perkawinan dalam keadaan pingsan atau tidak berdaya.

3. Pasal 289 KUHP

Dengan kekerasan atau ancaman kekerasa melakukan atau membiarkan dilakukannya perbuatan cabul yang menyerang kehormatan kesusilaan.

4. Pasal 290 KUHP

Perbuatan cabul kepada orang yang pingsan atau tidak berdaya.

\section{Penanganan dan Penegakan Hukum Tindak Pidana Kekerasan Dalam Rumah}

\section{Tangga}

Penanganan dalam tindak pidana KDRT dapat dilakukan dengan 2 (dua) penyelesaian yaitu melalui persidangan di pengadilan dan melalui mediasi penal. Untuk proses persidangan di pengadilan dimulai dari adanya laporan adanya KDRT oleh korban ataau keluarga atau orang lain namun dengan adanya surat kuasa kepada kepolisian yang berada di tempat kejadian perkara. Setelah adanya laporan maka pihak yang berwajib dalam 1 x 24 jam segera memberikan perlindungan sementara pada korban. Lalu dilanjutkan dengan penyelidikan serta penyidikan oleh Kepolisian 
dan dilanjutkan dengan penuntutan dan pemeriksaan di Pengadilan. Proses ini diakhiri dengan dikeluarkannya putusan oleh Majelis Hakim.

Untuk penyelesaian melalui mediasi penal dilakukan dengan berdasar pada Surat Kepala Kepolisian Negara Republik Indonesia Nomor Pol B/ 3022 / XII / 2009 / Sdeops tanggal 14 Desember 2009 tentang Penanganan Kasus Melalui Alternative Dispute Resolution (ADR), yeng menjelaskan pada intinya bahwa untuk segala tindak pidana yang memiliki kerugian kecil akan diselesaikan melalui musyawarah mufakat dengan kesepakatan para pihak dengan menghormati norma hukum sosial dan adat serta berdasarkan keadilan bagi kedua belah pihak.

Praktek mediasi penal dilakukan dengan mengakomodir kepentingan korban dan pelaku. Petugas Kepolisian dalam hal ini menjadi penengah untuk mencari solusi terbaik bagi kedua belah pihak. Fakta-fakta yang terjadi akan dipaparkan untuk mendapatkan kebenaran dan kemanfaatan dengan menghindari penyelesaian tanpa ada tekanan. ${ }^{10}$

Mediasi penal merupakan salah satu bentuk alternatif yang dilakukan di luar pengadilan dengan mempertemukan pelaku dan korban. Istilah lain dari mediasi penal merupakan Victim-Offender Mediation. Konsep dari mediasi penal diambil dari pemahaman restorative justice yang menekankan adanya dialog antara pelaku dan korban atas KDRT yang telah terjadi dan hal ini banyak diterapkan dan dianjurkan oleh pihak Kepolisian mengingat pelaku dan korban dalam satu lingkup rumah tangga. ${ }^{11}$

UU PKDRT tidak mengatur secara tegas mengenai penyelesaian tindak pidana KDRT melalui mekanisme mediasi penal. Namun meskipun tidak memiliki payung hukum yang kuat, mediasi penal ini banyak diterapkan oleh Penyidik Kepolisian dalam tahap penyidikan. Sehingga pelaksaan mediasi penal didasarkan atas kewenangan

${ }^{10}$ Iwan Kusnandang, "Perlindungan Hukum Oleh Polisi Republik Indonesia (Polri) Terhadap Saksi dan Korban Pada Proses Penyidikan Dalam Tindak Pidana Kekerasan Dalam Rumah Tangga Dikaitkan Dengan Undang - Undang Nomor 2 Tahun 2002 Tentang Kepolisian Republik Indonesia Juncto Undang - Undang Nomor 13 Tahun 2006 Tentang Perlindungan Saksi dan Korban”, Skripsi Program Sarjana Universitas Komputer Indonesia (Universitas Komputer Indonesia 2016).[47-48].

11 Sigid Riyanto, "Penerapan Mediasi Penal Oleh Penyidik Terhadap Tindak Pidana Kekerasan Dalam Rumah Tangga di Kepolisian Daerah Istimewa Yogyakarta", Skripsi Program Sarjana Universitas Gadjah Mada (Universitas Gadjah Mada 2016).[i]. 
diskresi yang mengacu pada Pasal 7 Ayat (1) Huruf J KUHAP dan Pasal 18 UndangUndang No 2 Tahun 2002 Tentang Kepolisian Negara Republik Indonesia. ${ }^{12}$

Penegakan hukum dapat dilakukan dengan mengacu pada asas legalitas yaitu perbuatan tidak dapat dipidana kecuali berdasarkan kekuatan perundang-undangan. Hal tersebut menunjukkan bahwa perbuatan yang dapat dipidana hanyalah perbuatan yang sudah diatur sebelumnya dalam peraturan perundang-undangan dan jika perbuatan yang belum atau tidak diatur maka tidak dapat dipidana. Oleh karena itu penegakan hukum dalam tindak pidana KDRT mengacu pada pasal dalam Bab VIII

UU PKDRT mengenai Ketentuan Pidana yaitu diantaranya:

(1) Pasal 44

Bagi setiap orang yang melakukan perbuatan fisik diancam penjara paling lama 5 (lima) tahun atau denda maksimal Rp.15.000.000 (lima belas juta rupiah), jika perbuatan mengakibatkan jatuh sakit atau luka berat maka diancam penjara paling lama 10 (sepuluh) tahun atau denda maksimal Rp.30.000.000 (tiga puluh juta rupiah), dan jika perbuatan mengakibatkan kematian maka diancam penjara paling lama 15 (lima belas) tahun atau denda maksimal Rp.45.000.000 (empat puluh lima juta rupiah). Namun jika perbuatan dilakukan suami terhadap isteri atau sebaliknya dan perbuatan tersebut tidak menimbulkan penyakit atau halangan untuk menjalankan pekerjaan jabatan atau mata pencaharian dan kegiatan seharihari maka diancam pidana penjara paling lama 4 (empat) bulan atau denda maksimal Rp. 5.000 .000 (lima juta rupiah).

(2) Pasal 45

Bagi setiap orang yang melakukan perbuatan kekerasan psikis dalam rumah tangga diancam pidana penjara paling lama 3 (tiga) tahun dan denda maksimal Rp.9.000.000 (sembilan juta rupiah) namun jika perbuatan dilakukan suami kepada isteri atau sebaliknya dan tidak menimbulkan penyakit atau halangan untuk menjalankan pekerjaan jabatan atau mata pencaharian dan kegiatan seharihari maka diancam pidana penjara paling lama 4 (empat) bulan atau denda maksimal Rp. 3.000.000 (tiga juta rupiah).

(3) Pasal 46

Bagi setiap orang yang melakukan kekerasan seksual dalam lingkup rumah tangga diancam pidana penjara paling lama 12 (dua belas) tahun atau denda maksimal Rp36.000.000 (tiga puluh enam juta rupiah).

(4) Pasal 47

Bagi setiap orang yang melakukan pemaksaan untuk melakukan hubungan seksual terhadap orang yang menetap di rumah tangganya diancam dengan pidana penjara paling singkat 4 (empat) tahun dan paling lama 15 (lima belas) 
tahun atau denda minimal Rp.12.000.000 (dua belas juta rupiah) dan maksimal Rp.300.000.000 (tiga ratus juta rupiah).

(5) Pasal 48

Bagi setiap perbuatan yang dimaksud dalam Pasal 46 dan Pasal 47 mengakibatkan luka yang tidak ada harapan untuk sembuh sama sekali dan mengalami gangguan piker atau jiwa sekurang - kurangnya 4 (minggu) dan hal tersebut terus menerus atau 1 (satu) tahun alat reproduksinya tidak berfungsi, diancam pidana penjara paling singkat 5 (lima) tahun dan paling lama 20 (dua puluh) tahun atau denda minimal Rp.25.000.000 (dua puluh lima juta rupiah) dan maksimal Rp.500.000.000 (lima ratus juta rupiah).

(6) Pasal 49

Bagi setiap orang yang menelantarkan orang lain dalam lingkup rumah tangganya diancam dengan pidana penjara paling lama 3 (tiga) tahun atau denda maksimal Rp.15.000.000 (lima belas juta rupiah).

\section{Implementasi Penanganan Korban Kekerasan Dalam Rumah Tangga}

Laporan Hasil Wawancara

Hari / Tanggal Pelaksanaan : Kamis, 14 November 2019

Waktu Pelaksanaan

: $10.00 \mathrm{WIB}$

Tempat Pelaksanaan

: Kantor Polres Kota Malang

Narasumber

: Tri Nawang Sari (Ketua Unit 2 Perlindungan

Perempuan dan Anak)

Tema Wawancara

: Perlindungan Korban Kekerasan Dalam Rumah

Tangga

Tujuan Wawancara

: Mengetahui Bagaimana Pelaksanaan,

Penanganan dan Perlindungan Korban

Kekerasan Dalam Rumah Tangga di Lapangan

Hasil Wawancara

Ibu Tri Nawang Sari yang menjabat sebagai Kepala Unit 2 Perlindungan Perempuan dan Anak menjelaskan bahwa di Polres Kota Malang sendiri dari tahun 2017 hingga 2019 cukup banyak menerima laporan terkait kasus KDRT yang korbannya kebanyakan adalah istri dan anak serta untuk jumlah kasus KDRT dikatakan cukup banyak presentasenya dibandingkan dengan kejahatan lain.

Pelapor kasus KDRT biasanya adalah korban sendiri. Korban yang melapor 
oleh Polres Kota Malang selanjutnya diarahkan kepada bagian Perlindungan Perempuan dan Anak atau yang biasa disingkat dengan PPA. Bentuk KDRT yang sering dialami oleh korban adalah kekerasan fisik, untuk kekerasan yang berbentuk psikis atau penelantaran ekonomi ada tapi jumlahnya sangat sedikit.

Faktor yang mendasari korban mendapat KDRT yaitu berkisar antara faktor ekonomi atau suami mempunyai WIL (Wanita Idaman Lain), untuk kasus yang korbannya PRT di Polres Kota Malang belum terdapat laporan namun Ibu Tri Nawang Sari mengatakan kemungkinan PRT menjadi korban KDRT dipicu oleh pekerjaan PRT yang kurang beres atau tidak benar, PRT yang ketahuan mencuri dan kejengkelan majikan.

Proses di Kepolisian setelah ada laporan masuk akan dilanjutkan ke tahap penyelidikan dan penyidikan namun kasus KDRT di Kota Malang jarang sekali yang masuk ke Pengadilan karena sebelum masuk Pengadilan kasus biasanya sudah dicabut duluan oleh korban karena adanya ketergantungan ekonomi korban kepada pelaku.

Terdapat alternatif lain sebagai pilihan untuk kasus KDRT selain dari kasus tersebut dibawa ke Pengadilan. Alternatif tersebut berupa mediasi penal yang ditawarkan oleh Kepolisian. Mediasi penal dilakukan dengan dimulai dari Kepolisian yang menelefon BHABINKAMTIBNAS yang merupakan polisi yang berada di bagian Kelurahan tempat pelaku dan korban tinggal untuk melakukan kesepakatan waktu antara BHABINKAMTIBNAS dengan pelaku dan korban KDRT untuk bertemu. Dalam hal ini BHABINKAMTIBNAS akan menengahi pertemuan yang membahas mengenai KDRT yang terjadi. Pertemuan akan dilakukan secara kekeluargaan dan diakhir pertemuan pelaku akan disuruh untuk membuat surat pernyataan untuk tidak mengulangi lagi perbuatannya. Jika pelaku mengulangi perbuatannya akan diproses secara pidana.

Untuk masalah perlindungan hukum kepada korban KDRT, Kepolisian hanya menangani proses pidananya. Untuk perlindungan Kepolisian bekerja sama dengan P2TP2A yang merupakan Pelayanan Terpadu Pemberdayaan Perempuan dan Anak. P2TP2A lah yang akan memberikan perlindungan kepada korban KDRT. Kendala dalam pemberian perlindungan kepada korban KDRT yaitu dalam hal visum yang 
merupakan kendala utama, karena bayarnya mahal dan tidak semua korban mampu membayar. Biaya visum minimal yaitu Rp. 350.000 (tiga ratus lima puluh ribu rupiah), biaya tersebut akan bertambah jika dokter meminta biaya tambahan lain.

\section{Kesimpulan}

Perlindungan hukum bagi PRT yang menjadi korban KDRT tercantum di beberapa peraturan perundang-undangan seperti UU PKDRT dan KUHP. Sedangkan ditinjau dari UU PKDRT, perlindungan untuk PRT yang menjadi korban KDRT meliputi perlindungan dari pihak Kepolisian, Tenaga Kesehatan, Pekerja Sosial, Relawan Pendamping, Pembimbing Rohani, dan Pelayanan Advokat. Untuk penanganan atas aduan korban KDRT terdapat 2 (dua) alternatif penyelesaian diantaranya setelah dilakukan penyelidikan dan penyidikan oleh Pihak Kepolisian akan dilanjutkan ke sidang pengadilan atau dapat juga dilanjutkan dengan mediasi penal yaitu dengan pertemuan secara kekeluargaan antara pelaku dan korban KDRT yang akan ditengahi oleh Pihak Kepolisian. Untuk mediasi penal ini belum diatur secara tegas dalam UU PKDRT sehingga pelaksanaannya berdasarkan kewenangan diskresi yang mengacu pada Pasal 7 Ayat (1) Huruf J KUHAP dan Pasal 18 Undang - Undang No 2 Tahun 2002 Tentang Kepolisian Negara Republik Indonesia. Padahal dalam praktiknya Pihak Kepolisian lebih banyak menerapkan dan lebih banyak menganjurkan penyelesaian melalui mediasi penal ini dibandingkan dengan proses peradilan karena pelaku dan korban memiliki kekerabatan yang kuat dan berada dalam satu lingkup rumah tangga.

\section{Daftar Bacaan}

\section{Buku}

Arif Gosita, Masalah Korban Kejahatan (Akademik Pressindo 1993).

Edriana Noerdin, Potret Kemiskinan Perempuan (Women Research Institute 2006).

Moerti Hadiati Soeroso, Kekerasan Dalam Rumah Tangga Dalam Perspektif Yuridis-Viktimologis (Sinar Grafika 2010).

Philipus M. Hadjon, Perlindungan Bagi Rakyat di Indonesia (PT Bina Ilmu 1987). 
Sidi Nazar Bakry, Kunci Keutuhan Rumah Tangga (Akademik Pressindo 1993).

\section{Jurnal}

Anggun Lestari Suryamizon, 'Perlindungan Hukum Preventif Terhadap Kekerasan Perempuan dan Anak Dalam Perspektif Hukum Hak Asasi Manusia' (2017) Jurnal Perempuan, Agama dan Jender UIN Suska.

\section{Perundang-undangan}

Undang-Undang Dasar Negara Republik Indonesia Tahun 1945.

Undang-Undang Republik Indonesia Nomor 1 Tahun 1946 Tentang Peraturan Hukum Pidana juncto Undang-Undang Nomor 73 Tahun 1958 (Lembaran Negara Nomor 172 Tahun 1958, Tambahan Lembaran Negara Nomor 1660 Tahun 1958) Tentang Menyatakan Berlakunya Undang-Undang Nomor 1 Tahun 1946 Republik Indonesia Tentang Peraturan Hukum Pidana Untuk Seluruh Wilayah Republik Indonesia dan Mengubah Undang-Undang Hukum Pidana.

Undang-Undang Republik Indonesia Nomor 23 Tahun 2004 Tentang Penghapusan Kekerasan Dalam Rumah Tangga (Tambahan Lembaran Negara Nomor 4419)

Peraturan Menteri Ketenagakerjaan Nomor 2 Tahun 2015 Tentang Perlindungan Pekerja Rumah Tangga (Berita Negara Republik Indonesia Tahun 2015 Nomor 78)

\section{Makalah}

Iwan Kusnandang, "Perlindungan Hukum Oleh Polisi Republik Indonesia (Polri) Terhadap Saksi dan Korban Pada Proses Penyidikan Dalam Tindak Pidana Kekerasan Dalam Rumah Tangga Dikaitkan Dengan Undang-Undang Nomor 2 Tahun 2002 Tentang Kepolisian Republik Indonesia Juncto Undang-Undang Nomor 13 Tahun 2006 Tentang Perlindungan Saksi dan Korban", Skripsi Program Sarjana Universitas Komputer Indonesia (Universitas Komputer Indonesia 2016).

Igid Riyanto, "Penerapan Mediasi Penal Oleh Penyidik Terhadap Tindak Pidana Kekerasan Dalam Rumah Tangga di Kepolisian Daerah Istimewa Yogyakarta", Skripsi Program Sarjana Universitas Gadjah Mada (Universitas Gadjah Mada 2016).

Syahrul Ramadhan, "Perlindungan Hukum di Bidang Kesehatan Bagi Masyarakat di Desa Tamansari Kecamatan Mumbulsari Kabupaten Jember", Skripsi Program Sarjana Universitas Jember (Universitas Jember 2015). 